IZA DP No. 7756

Absence from Work of the Self-Employed:

A Comparison with Paid Employees

Daniel S. J. Lechmann

Claus Schnabel

November 2013 


\title{
Absence from Work of the Self-Employed: A Comparison with Paid Employees
}

\author{
Daniel S. J. Lechmann \\ University of Erlangen-Nuremberg \\ Claus Schnabel \\ University of Erlangen-Nuremberg \\ and IZA
}

Discussion Paper No. 7756

November 2013

\author{
IZA \\ P.O. Box 7240 \\ 53072 Bonn \\ Germany \\ Phone: +49-228-3894-0 \\ Fax: +49-228-3894-180 \\ E-mail: iza@iza.org
}

\begin{abstract}
Any opinions expressed here are those of the author(s) and not those of IZA. Research published in this series may include views on policy, but the institute itself takes no institutional policy positions. The IZA research network is committed to the IZA Guiding Principles of Research Integrity.

The Institute for the Study of Labor (IZA) in Bonn is a local and virtual international research center and a place of communication between science, politics and business. IZA is an independent nonprofit organization supported by Deutsche Post Foundation. The center is associated with the University of Bonn and offers a stimulating research environment through its international network, workshops and conferences, data service, project support, research visits and doctoral program. IZA engages in (i) original and internationally competitive research in all fields of labor economics, (ii) development of policy concepts, and (iii) dissemination of research results and concepts to the interested public.
\end{abstract}

IZA Discussion Papers often represent preliminary work and are circulated to encourage discussion. Citation of such a paper should account for its provisional character. A revised version may be available directly from the author. 
IZA Discussion Paper No. 7756

November 2013

\section{ABSTRACT \\ Absence from Work of the Self-Employed: A Comparison with Paid Employees}

Utilising a large representative data set for Germany, this study contrasts absenteeism of self-employed individuals and paid employees. We find that absence from work is clearly less prevalent among the self-employed than among paid employees. Only to a small extent, this difference can be traced back to differences in health status and job satisfaction. Furthermore, the gap in absenteeism is apparently not driven by different behaviour in case of sickness as we find no difference in the prevalence of presenteeism between the two groups. We suspect that different behaviour in case of healthiness plays a role, highlighting potential shirking and moral hazard problems in paid employment.

JEL Classification: I19, J22, J23

Keywords: absenteeism, Germany, self-employed, sick leave

Corresponding author:

Claus Schnabel

University of Erlangen-Nürnberg

Chair of Labour and Regional Economics

Lange Gasse 20

90403 Nürnberg

Germany

E-mail: Claus.Schnabel@wiso.uni-erlangen.de

* For helpful comments and suggestions, we would like to thank Harald Tauchmann and participants in the Workshop on Sickness Absence and Presenteeism in Trier, October 2013. 


\section{Motivation}

Absence from work is a pervasive phenomenon that is costly to enterprises and society as it is associated with an underutilisation of labour and corresponding productivity losses. A number of empirical studies have tried to quantify the extent of worker absence (for reviews of the international evidence, see Lusinyan and Bonato 2007, Livanos and Zangelidis 2013). Typical findings are that the number of working days lost due to (sickness-related) absence is comparable to the number of working days lost due to unemployment and much higher than the number of working days lost due to strikes (Brown and Sessions 1996), that absence rates vary substantially between countries (Lusinyan and Bonato 2007, Frick and Malo 2008, Livanos and Zangelidis 2013), and that the incidence and duration of absence from work fluctuate with the business cycle (Audas and Goddard 2001, Askildsen et al. 2005, Pfeifer 2013). These studies, however, focus almost exclusively on absence from work by workers in paid employment, thus neglecting the number of working days lost in selfemployment. This information deficit is most unfortunate as absence from work of self-employed persons may have more severe consequences in terms of productivity losses than the absence of paid employees, given that self-employed firm owners may provide inputs that cannot easily be substituted for by other workers.

There are several strands of the literature that try to provide explanations and theoretical analyses of absence from work and its determinants from various perspectives. Economists have tended to analyse absence within the framework of the static neoclassical labour supply model as the result of an individual's labourleisure choice, or they have made use of efficiency wage and contractual models (for a review of this literature, see Brown and Sessions 1996). While these approaches may be well suited for explaining the behaviour of workers in dependent employment, they are less able to explain the behaviour of the self-employed who are their own employers. They also ignore the state of health of individuals that is the centre of the medical statistics literature. Occupational health researchers, psychologists and sociologists further stress the importance of working conditions, workplace atmosphere, motivation, and job satisfaction (see Beemsterboer et al. 2009). The various perspectives taken give rise to a large number of potential determinants of sick leave and absence from work. 
Although empirical studies on the determinants of absence from work by economists, psychologists, sociologists, and occupational health researchers are legion (for reviews, see Thalmaier 2002, Allebeck and Mastekaasa 2004, Osterkamp and Röhn 2007, Beemsterboer et al. 2009), these studies usually focus exclusively on workers in paid employment. Empirical research on work absence of the self-employed is thus very scarce. For the self-employed, there exist some studies for absence from work for specific groups such as farmers (Hartman et al. 2003) and for long-term disability (Bakker et al. 2006; see also Yelin et al. 1980). In a comprehensive study of sickness absence of self-employed individuals, Spierdijk et al. (2009) report that several risk factors (such as age and psychological diseases) affect the sick leave durations of Dutch self-employed in a similar way as they are known to influence the absence spells of paid employees according to the literature, whereas other factors (such as high unemployment) seem to work differently. Unfortunately their data set does not enable the authors to directly compare workers in self-employment and paid employment. Analysing Finnish time use data, Hyytinen and Ruuskanen (2007) report that the self-employed are less frequently absent from work than paid employees, but they do not specifically investigate work absence and its determinants. That self-employed individuals exhibit significantly fewer days of absence than paid employees is also found by Pfeifer (2013) for Germany in the period 1995 to 2007. However, in his brief study of cyclical absenteeism Pfeifer (2013) does not investigate whether the determinants of absence (apart from the unemployment rate) differ between the two groups. ${ }^{1}$ Thus, there is a lack of studies that compare absence from work and its determinants between workers in paid employment and in self-employment.

Such a comparison should be worthwhile because the incentive structure regarding (sickness) absence differs strongly between paid employees and self-employed persons. Principal-agent problems resulting from asymmetric information between paid employees and their employers that may affect absenteeism of paid employees do not play a role for the self-employed who are their own employers. Since the self-

\footnotetext{
${ }^{1}$ Some results for self-employed individuals are also mentioned in a small descriptive study on workrelated sickness absence with UK data by Hussey et al. (2012), in an econometric investigation of transitions in and out of sickness with Danish data by Pedersen et al. (2012), and in an analysis of doctoral and hospital visits in West Germany by Riphahn et al. (2003).
} 
employed do not receive any sick pay for the first couple of days of absence, whereas paid employees in Germany receive 100 percent sick pay from the first day, they also face fewer problems of moral hazard. These distinct differences in incentives should result in lower absence from work of self-employed individuals than of paid employees.

Against this background, this paper contributes to the literature mainly in three ways: First, using a large representative data set for Germany, we are able to calculate and compare the incidence and extent of absence from work by individuals in selfemployment and in paid employment, finding substantial differences between both groups. Second, based on theoretical considerations from various disciplines, we analyse the determinants of work absence in self-employment and show how they differ from those of workers in dependent employment. Third, we investigate whether the gap in absenteeism is mainly driven by different behaviour in case of sickness or in case of healthiness, pointing to potential shirking and moral hazard problems. ${ }^{2}$

The paper is structured as follows: Section 2 provides a brief overview of the theoretical and empirical literature on absence from work and discusses whether its insights are equally relevant for individuals in dependent and in self-employment. Our data and some descriptive evidence are presented in section 3. Section 4 reports the results of our econometric study which analyses the probability of ever having been absent and the number of days of absence conditional on ever having been absent both for self-employed persons and paid employees. Finally, section 5 provides some concluding remarks.

\section{Theoretical and empirical literature}

The vast theoretical and empirical literature on the determinants of absence from work of employees in dependent employment can be categorised in various ways, for

\footnotetext{
${ }^{2}$ Note that in this paper we take absenteeism to include all kinds of absence from work on workdays for whatever reason, be it sickness, withdrawal from the workplace or actively trying to reach a better labour-leisure time allocation. This approach seems sensible, given the massive methodological problems to differentiate between voluntary and involuntary absence and the fact that even a doctor's certificate merely reflects his subjective assessment of the patient's health situation and his fitness for work.
} 
instance according to the academic disciplines involved. In the following, we will classify the literature according to those factors (or group of variables) it mainly focuses on, ranging from health and working conditions over labour supply considerations and working hours to job (dis)satisfaction and insurance issues. As "there are no economic models explaining absenteeism among self-employed" (Spierdijk et al. 2009, 1188), this approach enables us to discuss whether the insights of the respective literature are equally relevant for individuals in dependent and in self-employment and to test this with our data.

Individuals' state of health as the prime determinant of absence from work is emphasized in the medical statistics literature, which therefore usually speaks of "sickness absence" or "sick leave". Relatedly, occupational health researchers stress the importance of unhealthy working conditions, physical and mental workload, and other work circumstances. This strand of the literature mostly concentrates on the empirical analysis of health statistics and surveys rather than on rigorous theoretical analysis. However, the relevance of adverse working conditions, which make absence from work more likely by increasing employees' disutility from work, can also be derived in standard economic models (such as Allen 1981). Not surprisingly, there is a large number of empirical studies showing that the frequency and duration of (sickness) absence is significantly related to health and work characteristics such as health complaints, perceived workload, work strain, work content and working conditions (see, e.g. Leigh 1991, the survey by Beemsterboer et al. 2009, the metaanalysis by Darr and Johns 2008, as well as Thalmaier 2002 and Beblo and Ortlieb 2012 for evidence on Germany). While this empirical literature almost exclusively concentrates on individuals in paid employment, there are no compelling reasons to assume that the importance of health and work characteristics should not carry over to individuals in self-employment.

Working time is another potential determinant of absenteeism mainly emphasized by economists. Allen (1981) develops an economic model in which absence from work is interpreted as a form of leisure in a standard neoclassical labour supply model. Absenteeism is seen as a worker's strategy to bring actual hours worked in line with desired hours if the working hours fixed in the job contract are higher than individuals' desired hours. Workers will be absent whenever the benefits of missing work are 
greater than its costs, such as wage losses, and they are more likely to be absent, the higher sickness benefits are and the less flexible work schedules are (for a review of this strand of literature, see Brown and Sessions 1996). There exist a number of empirical studies showing that working hours and working time arrangements play a role in explaining absenteeism of workers in dependent employment, although not all empirical results fully satisfy theoretical expectations (see, e.g. Dionne and Dostie 2007, Lusinyan and Bonato 2007, and Thalmaier 2002 for Germany). In contrast to paid employees, who are usually subject to working hours constraints, working time should be of lesser relevance for the self-employed since the latter are their own employers and thus have no job contract specifying fixed working hours. That said, excessive working hours and unhealthy working time arrangements should of course affect both groups in a similar way by impairing their health. By comparing individuals in self-employment and dependent employment, we may thus learn more about the importance of working time for explaining absence from work.

Job dissatisfaction is a further motive for being absent from work, which has been stressed for a long time mainly by applied psychologists (see, e.g. the influential paper by Steers and Rhodes 1978). This subjective measure of well-being may reflect a wide range of unsatisfying factors at the workplace such as low psychological control over the work situation, frustrating experiences at work, unpleasant or hazardous working conditions, and deficits in employer-employee communication. In a substantial number of empirical studies, job (dis)satisfaction has been found to affect absenteeism of individuals in dependent employment (see, e.g. Böckerman and Ilmakunnas 2008 as well as the surveys by Allebeck and Mastekaasa 2004 and by Beemsterboer et al. 2009). In principle, job (dis)satisfaction can be expected to play a similar role for the absence from work of individuals in dependent and in self-employment. However, as self-employed individuals are in a better position to choose, influence, and control their work situation, they should be more satisfied with their work, and this has been empirically confirmed in various studies (see, e.g. Blanchflower and Oswald 1998, Hundley 2001, Benz and Frey 2008). This suggests that absenteeism due to job dissatisfaction should be less prevalent among the self-employed than among paid employees. 
The incentive of being absent from work and thus absenteeism should be higher, the lower the costs or penalties are that workers face in case of absence. This relationship can be derived in various kinds of economic models (see, e.g. Allen 1981, Barmby et al. 1994, and Engström and Holmlund 2007), and it is confirmed by a number of international empirical analyses that compare the effects of different sickness benefit systems across countries (see Osterkamp and Röhn 2007, Lusinyan and Bonato 2007, Frick and Malo 2008). For Germany, various analyses of the 1996 reform in the generosity of the sickness insurance system and of its revocation have found that reducing (increasing) sick pay significantly reduces (increases) absence of workers in dependent employment (see, e.g. Puhani and Sonderhof 2010, Ziebarth and Karlsson 2013). In Germany, paid employees nowadays do not suffer any immediate monetary costs in case of sickness absence. From the first day of absence they receive 100 percent sick pay paid by the employer, and after six weeks of absence (when sickness insurance takes over) this share is reduced to 70 percent of gross wages. While the self-employed may also receive the 70 percent sick pay beginning in the seventh week of sickness, they do not get any sick pay for the first couple of days of absence. If voluntarily covered by private sickness insurance they may receive a certain amount of sick pay after some (minimum three) waiting days, but there is no private insurance company offering sick pay without any waiting days. Another major difference is that the self-employed have to bear the costs of production losses themselves, whereas paid employees can pass these costs on to the firm they are working for. What is more, production losses may be more severe in the case of self-employed workers as they often provide inputs that are rather hard to substitute for by other workers. Although the self-employed do not face some penalties that paid employees may experience in case of (excessive) absenteeism, such as reduced career opportunities, the costs of absence are certainly higher for the self-employed, and so the prevalence and extent of absenteeism should be lower for this group.

Asymmetric information, principal-agent problems, and shirking are further aspects that - in an economic perspective - might play a role in explaining (voluntary) absence from work. Given the moral hazard of 100 percent sick pay as well as asymmetric information between workers and their employer regarding workers' actual health, paid workers may claim sick pay despite being in good health, thus 
driving up absence rates. Paying higher "efficiency" wages is one way in which firms may overcome this shirking problem (see Barmby et al. 1994). While there are some indications of shirking in empirical studies of workers in dependent employment (see Johansson and Palme 1996), shirking should not play a role for absenteeism of selfemployed individuals who are their own employers. Here, the principal-agent and asymmetric information problem is between the self-employed individual, who is much better informed about his or her health and risk of absence, and the insurance company (cf. Spierdijk et al. 2009). As sick pay insurance is optional for the selfemployed, adverse selection poses another problem for private insurance companies, resulting in more complex contractual arrangements, waiting days, and even denial of sick pay coverage. These aspects suggest that the incentives to report sick are lower for the self-employed than for workers in dependent employment.

Many empirical studies of absence from work also include socio-demographic characteristics of employees such as age, sex, qualification, household context and nationality as potential explanatory variables even if the theoretical basis of their inclusion is often weak (see the literature reviews by Allebeck and Mastekaasa 2004 and Beemsterboer et al. 2009, and Thalmaier 2002 and Beblo and Ortlieb 2012 for Germany). Empirical findings for persons in dependent employment vary considerably and partly seem to depend on whether the crucial determinants discussed above such as health status, working conditions, and job (dis)satisfaction have also been included in the analysis. It seems thus sensible to regard sociodemographic characteristics primarily as control variables without attempting to predict in which way they should affect individuals in dependent and self-employment differently. ${ }^{3}$

All in all, these considerations based on a brief review of the literature suggest that there are a number of factors (or groups of variables) that should affect the absence from work of paid workers and self-employed individuals in a similar way. These include individuals' state of health, unhealthy working conditions, and other work characteristics. In contrast, working hours and job (dis)satisfaction can be expected to be less relevant for the work absence of self-employed persons. There are also

\footnotetext{
${ }^{3}$ Further variables at the firm level that have been found to affect absence rates of paid employees but which cannot be expected to play a similar role for self-employed individuals are firm size (see, e.g. Dionne and Dostie 2007) and teamwork (Heywood and Jirjahn 2004).
} 
some factors such as sick pay, principal-agent problems and the opportunities for shirking that play a different role for individuals in dependent and in self-employment. Due to different insurance contracts and higher costs of absence the incentives to stay home sick are clearly lower for the self-employed than for workers in dependent employment. We would therefore expect to find that the incidence and duration of absence from work is lower for the self-employed (even when controlling for health status, working conditions and job satisfaction).

\section{Data and descriptive evidence}

The data set used in this study is the BIBB/BAuA Employment Survey of the Working Population on Qualification and Working Conditions in Germany 2012 (Hall et al. 2012; see Rohrbach-Schmidt \& Hall 2013 for a more detailed description). This rich data set contains information on a representative sample of more than 20,000 individuals from the German active labour force population who are at least 15 years old and regularly work at least 10 hours per week. Among others, the data provide information on the number of days and cases of sickness absence as well as on the number of days and occasions individuals went to work despite being sick. In addition, there is information on the subjective health status of individuals and on the types of afflictions individuals received medical treatment for. This makes the data especially suitable for the present analysis of absenteeism.

Our sample consists of 1,700 self-employed individuals and 9,837 paid employees. The self-employed are made up of tradesmen (who are coded as "Selbständige" in the data) and liberal professionals (coded "freiberuflich Tätige" in the data) whereas the paid employees include all blue-collar and white-collar workers who are working for firms in the private sector. We exclude employees working in the public sector or for private households since these two sectors do not comprise self-employed persons in our data. We also exclude helping family members and freelance collaborators since they are neither typical self-employed nor paid employees.

(Table 1 about here) 
As can be seen in Table 1, there are distinct differences in the absence from work of self-employed individuals and workers in paid employment. First of all, the question whether they "have stayed home sick or called in sick in the last 12 months" was answered in the affirmative by only 22 percent of the self-employed but 51 percent of paid employees. Put differently, the large majority (namely 78 percent) of the selfemployed report never having stayed home sick in the last 12 months. Accordingly, the average number of occasions of sickness absence is only about 0.4 for the selfemployed, whereas it amounts to about 0.9 for the paid employees. The difference in sickness absence between these groups is even more pronounced when looking at the total number of workdays lost. While the average number of sick days reported by the self-employed is about 3 workdays, paid employees on average have three times as many sick days, namely 9 workdays in the last 12 months. It is thus clear that the incidence and the extent of absence from work are much lower for the self-employed, which corresponds to our expectations. ${ }^{4}$

The substantial difference in the average numbers of occasions and days of absence is heavily driven by the fact that many more self-employed than paid employees report never having stayed home or called in sick at all in the last 12 months (thus having zero occasions and days of sick-leave). When only looking at the sickness absence of those who were absent at least once, there is no difference anymore between self-employed and paid employees in the average number of occasions of sickness absence. Regarding the number of sick days, however, those self-employed who were absent at least once again report fewer sick days than the respective group of paid employees (namely 14 days as compared to 18 days).

One reason why the incidence and the extent of absence from work are much lower for the self-employed might be that they more frequently show up at work despite feeling sick because they feel that they cannot afford to miss work (or because they are more easily able to adjust their work intensity to their impaired health). Our data, however, do not support this explanation. Table 1 displays the number of times individuals went to work despite that (in their own judgment) they should have stayed home due to sickness, a phenomenon that has been called "presenteeism" (see

\footnotetext{
${ }^{4}$ The reported sick-leave data may suffer from recall bias. This would only be a problem for our analysis, however, if this bias systematically differs between paid employees and the self-employed. We have no reason to believe that this is the case.
} 
Chatterji and Tilley 2002 and the review by Johns 2009). 48 percent of the selfemployed report that they went to work despite sickness at least once in the last 12 months, whereas 53 percent of the paid employees did so. While the number of times of going to work despite sickness is slightly higher for the self-employed than for paid employees (2.2 versus 1.9 occasions), the number of days is slightly lower (5.2 versus 5.9 days).

As the observed difference in absence from work is apparently not driven by different behaviour in case of sickness, two remaining explanations are different behaviour in case of healthiness and differences in health status. Starting with the latter, the selfemployed may stay home sick less often simply because they are healthier than paid employees. An advantage of our data set is that it contains information not only on the subjectively reported health status of individuals (on a five-point Likert scale) but also on the types of afflictions that actually received medical treatment in the last 12 months. ${ }^{5}$ This makes it possible to account for the health status of individuals rather precisely. Table 1 shows that on average the self-employed are indeed somewhat healthier than paid employees. 91 percent of the self-employed report at least good health status (i.e. they describe their health status as being excellent, very good, or good), while this is only the case for 87 percent of paid employees. On average the self-employed received medical treatment for 1.2 different types of afflictions in the last 12 months whereas this number amounts to 1.7 for paid employees. This difference in health status may explain part of the difference in absence from work and we will examine this link between health status and sickness absence in the econometric analysis in section 4 .

As explained in section 2, the economic literature emphasises the importance of working hours and working time constraints as determinants of absenteeism. If the self-employed have more flexibility in scheduling their working time than paid employees, absenteeism should be less prevalent amongst the former. However, our data do not support the presumption that the self-employed enjoy more working time flexibility (see Table 1). To begin with, the self-employed work considerably more hours than paid employees, namely 45 vs. 38 hours per week on average. Given this

\footnotetext{
${ }^{5}$ There are 24 different types of afflictions for which information on medical treatment was collected, e.g. low back pain, headaches, coughing, eye problems, night-time sleeping disorders, depression, physical exhaustion.
} 
high workload, it is not surprising that only 57 percent of the self-employed report often being able to take family and private interests into account when scheduling their working time, whereas 60 percent of paid employees do so. This implies that in practice paid employees are not worse off in terms of working time flexibility than the self-employed and that working time scheduling may not contribute much in explaining differences in absenteeism between paid employees and the selfemployed.

As mentioned in section 2, the self-employed are usually found to be more satisfied with their work than paid employees are, and this also shows up in our data. 41 percent of the self-employed report being very satisfied with their work, whereas only 27 percent of paid employees do so. The distinctly lower job satisfaction of paid employees is likely to result in a higher incentive of being absent from work and may explain why absenteeism is more prevalent amongst paid employees.

Finally, Table 1 shows that self-employed and paid employees differ considerably with respect to some socio-demographic variables. The share of women is much lower in self-employment than in paid employment and the self-employed are older on average than paid employees, patterns well known in the literature (cf. Parker 2009: 184, 108). The self-employed also differ from paid employees in that they are better educated on average. 43 percent of the self-employed but only 20 percent of paid employees have a university degree. These differences will be accounted for in the following econometric analysis.

\section{Econometric analysis}

The descriptive evidence discussed above has made clear that the difference in the average number of occasions and days of absence between self-employed and paid employees is mainly driven by the fact that only few self-employed persons report occasions or days different from zero while more than twice as many paid employees report strictly positive numbers. When analysing the absenteeism of both groups, we 
will take this pattern into account by estimating hurdle regression models. ${ }^{6}$ Hurdle models consist of two functionally independent parts: a binary model to deal with zeros, and a truncated count data model for the number of events conditional on having a strictly positive number of events (cf., e.g. Long and Freese 2006: ch. 8.5). Correspondingly our multivariate analysis consists of two parts. First, we focus on the difference in the probability of having ever been absent between the self-employed and paid employees, utilising Probit regressions (section 4.1). In a second step, we then have a look at the number of absence days conditional on ever having been absent, making use of truncated negative binomial regressions (section 4.2).

\subsection{Probability of ever having been absent}

Table 2 displays the results (average partial effects) of Probit regressions of the probability of ever having stayed home sick or called in sick in the last 12 months. When estimating a pooled model not accounting for differences in observable characteristics (column 1), the probability of ever having been absent is 29 percentage points lower for the self-employed than for paid employees. This corresponds to the descriptive evidence reported in Table 1.

In the second column of Table 2 we now add several groups of control variables to account for observable differences between the self-employed and paid employees. First of all, we take health status into account by including 4 dummies for selfassessed health status and 24 dummies for each affliction that received medical treatment in the last 12 months. We account for differences in working time by including weekly working hours, a dummy indicating whether one is often able to take family and private interests into account when scheduling working time, and three dummies indicating whether individuals work on Saturdays, Sundays, or between 7 am and $7 \mathrm{pm}$. Since stress, bad working conditions, and job satisfaction are likely to influence absence from work we include 2 dummies for job satisfaction, 2 dummies

\footnotetext{
${ }^{6}$ An alternative is the zero-inflated negative binomial model (cf., e.g. Long and Freese 2006: ch. 8.6). However, this model is based on the assumption that there exist "excessive zeros", i.e. that it is impossible to have strictly positive numbers of events for some individuals. This would, for instance, be the case if some individuals were not in the workforce and so necessarily would have zero absent days. Since we only look at individuals from the active labour force population, such "excessive zeros" are unlikely to occur and thus the hurdle model seems to be more appropriate. Nevertheless, we will also run zero-inflated negative binomial models as a robustness check. For a comparison of zeroinflated and hurdle models, see Rose et al. (2006).
} 
indicating whether the workload is over- or under-challenging, 3 dummies indicating emotional strain at work, and 23 dummies for several stressful working conditions, such as dirt, noise, coldness, dazzling light, repetitive work, high time pressure, or high pressure to perform. Socio-demographic variables like sex, age (linear and squared), migration background, education, and family background are also included. Finally, 16 dummies for the German federal states and 21 industry dummies account for regional and industry factors. ${ }^{7}$

Table 2 shows that even with this rich set of control variables the difference in the probability of ever having been absent still amounts to 23 percentage points and is statistically significant at the 1 percent level. While health status, working time arrangements, job satisfaction, and stressful working conditions do play a certain role for absence from work, they do not seem to explain much of the difference in sickleave between self-employed and paid employees. ${ }^{8}$

Running separate regressions for individuals in self-employment and paid employment enables us to have a closer look at the coefficients of the explanatory variables and examine whether these variables play different roles for both groups (see columns 3 and 4 of Table 2). Starting with the group of variables reflecting health status, it is apparent that a better state of health is associated with less frequent absence from work for both groups. The dummies for subjective health status and medical treatments received are jointly statistically significant at the 1 percent level for paid employees as well as for the self-employed. While paid employees seem to react somewhat more sensitive to health status (e.g. reporting an excellent instead of a good health status is associated with a 14.7 percentage points lower probability of ever having been absent for paid employees but only a 6.5 percentage points lower probability for the self-employed), the confidence intervals of

\footnotetext{
${ }^{7}$ Although we have some information on earnings in our data set, we do not include this variable for two reasons. First, the questions on earnings are not identical for self-employed and paid employees, and there are several measurement problems (e.g. regarding capital income, gross/net income). Second, monthly earnings are probably endogenous as sickness absence is likely to result in lower profits for the self-employed.

${ }^{8}$ When decomposing the difference in the probability of having been absent using the Fairlie (2005) method, it turns out that only 6 out of the 29 percentage points difference can be explained by differences in endowments (corresponding to the 6 percentage points decrease of the difference between our univariate and multivariate Probit regressions in columns 1 and 2, respectively). About 4 percentage points can be explained by the difference in health status between self-employed and paid employees, 1 percentage point by differences in job satisfaction and strains, and 2 percentage points by socio-demographic factors.
} 
the average partial effects for both groups overlap, suggesting that they are not statistically significantly different.

In contrast, working time arrangements do not seem to play a similar role for the absence of self-employed and paid employees, which is in accordance with theoretical expectations. For the self-employed, the respective variables (working hours, ability of taking family and private interests into account, working Saturdays, etc.) are not jointly statistically significant. The same variables are statistically significant at the 5 percent level for paid employees, but the average partial effects do not always show the expected direction. In particular, a more flexible working time scheduling seems to be positively related to absence from work, which is at odds with theoretical expectations based on the neoclassical model of labour-leisure choice.

The group of variables reflecting job satisfaction and the (dis)utility of work seem to be of similar importance for the absence of work of paid employees and the selfemployed. For both groups of individuals, job satisfaction, challenging workload, emotional strain, and stressful working conditions are jointly statistically significant at the 1 percent level. Looking at job satisfaction, for the self-employed being very satisfied with the job rather than less or not satisfied is associated with a reduction in the probability of ever having been absent by 14.5 percentage points, ceteris paribus (whereas this effect is quantitatively smaller but not statistically significantly different for paid employees).

Finally, it should be mentioned that there seems to be no big gender difference in the probability of having been absent from work within the past 12 months, ceteris paribus. After controlling for health status, working time arrangement, job satisfaction, and working conditions the female dummy is not statistically significant in either the regression for paid employees or for the self-employed, which is why we decided not to estimate separate models for men and women.

All in all, the analysis shows that health status, job satisfaction, strains, and working conditions are important factors associated with the incidence of absence from work of both self-employed and paid employees. Still, differences in these variables 
between the two groups do not contribute much to explaining the difference in absence between the self-employed and paid employees.

\subsection{Days of absence conditional on having been absent at least once}

After examining the incidence of absence from work we now look at the extent of absenteeism, as measured in the number of working days lost. Rather than analysing the total number of days of absence for all individuals (including those who were never absent), we only look at the number of working days lost of those persons who actually were absent at least once. This takes account of the phenomenon stressed above that the difference in the average number of absent days between selfemployed and paid employees is mainly driven by the fact that only very few selfemployed report absence days different from zero, whereas many more paid employees report strictly positive numbers of days of absence. However, the results of the following regressions should be interpreted with a pinch of salt. Conditioning on strictly positive numbers of days of absence may result in a selection bias (cf. Angrist and Pischke 2009: 99-102), unless the incidence and the extent of absenteeism are independent (after controlling for observable factors). ${ }^{9}$

Table 3 displays the results of truncated negative binomial regressions for the number of absence days of those individuals who were absent at least once, including the same explanatory and control variables as in the previous regressions. Conditional on ever having been absent, the extent of absence from work is on average 3 days lower for the self-employed than for paid employees (column 1). When including our explanatory and control variables, the self-employment dummy is still negative (-1.6 days), but not statistically significant anymore (column 2 ).

Health status and treatments received are again jointly statistically significant (at the 1 percent level) for both the self-employed and paid employees. In contrast to the findings above, it seems that the number of days absent from work reacts more sensitive to health status for the self-employed than for paid employees. For instance, reporting excellent health status instead of good health status is associated

\footnotetext{
${ }^{9}$ Furthermore, our data set does not provide variables that could serve as convincing exclusion restrictions in a selection correction model.
} 
with 10.8 fewer days of absence for the self-employed but only with 4.4 fewer working days lost for paid employees. Likewise, working time arrangements as well as job satisfaction, strains, and working conditions seem to be relevant for the extent of absenteeism of both self-employed individuals and paid employees. Both groups of variables are jointly statistically significant at the 5 percent level for the selfemployed and at the 1 percent level for paid employees. Thus, for those persons who were absent from work at least once, the absence behaviour of individuals in selfemployment and dependent employment is largely similar and related to the same groups of variables.

Comparing both stages of our hurdle model, it is interesting that age is negatively related to the probability of ever having been absent (Table 2), whereas it is positively related to the number of days absent from work (Table 3). This is in line with findings in the literature that older people are absent less frequently, but if they call in sick, they are usually absent for a longer period of time (see, e.g. Thalmeier 2002).

Note that our insights still hold when performing a number of robustness checks. For instance, we divided our sample of self-employed individuals into those with and without employees (the latter sometimes being called solo self-employed). In both groups just 22 percent of individuals report ever having been absent from work in the last 12 months, and the estimation results of the hurdle model for the incidence and extent of absenteeism are quite similar. As some self-employed individuals may be working at home, the question whether they stayed home sick could be difficult to answer precisely. Therefore, we excluded some professional fields where working at home can be expected to be more prevalent (such as artists, musicians, designers, publicists, and agriculture) which did not affect our results. Furthermore, we replaced the two-step hurdle model by a zero-inflated negative binomial model for the total number of working days lost (including zeros). The results indicate that excessive zeros do not seem to play an important role so that our use of the more easily interpretable hurdle model is justified.

\section{Conclusions}


Utilising a large representative data set for Germany, this study has compared and analysed absence from work of self-employed individuals and paid employees. We have found, in line with recent results for Germany (Pfeifer 2013), that absenteeism is clearly less prevalent among the self-employed since paid employees on average report three times as many days of absence than self-employed individuals. This substantial difference in the average number of working days lost is largely driven by the fact that many more self-employed than paid employees report zero days of sickleave. In the past 12 months, only 22 percent of the self-employed report having been absent at least once, whereas 51 percent of paid employees do so.

A deeper investigation into the determinants of absence has shown that differences in working time, working conditions and job satisfaction of self-employed individuals and paid employees are not able to explain a substantive part of the gap in absenteeism, and differences in health status only play a minor role. Furthermore, the difference in sick-leave is apparently not driven by different behaviour in case of sickness as we find no difference in the prevalence of presenteeism between the two groups. Taken together, these findings imply that the large difference in absenteeism at least partly results from different behaviour in case of healthiness, pointing to potential shirking and moral hazard problems in paid employment.

There are good reasons to believe that the incentives for calling in sick despite being in good health are much stronger for paid employees than for self-employed individuals. In Germany, paid employees receive 100 percent sick pay from the first day of absence, whereas there exist no insurance contracts without any waiting days for the self-employed. Furthermore, employers are not able to obtain full information about the actual health status of their employees, which causes principal-agent problems that do not apply in self-employment. When having obtained a medical certificate of incapacity for work, paid employees tend to be absent for the full period certified (probably because they assume that showing up for work sooner would be on their own risk) whereas self-employed individuals may start to work again as soon as possible because they themselves have to bear the consequences of the production losses that result from being absent. These distinct differences in incentive structures combined with our finding of substantially different absenteeism behaviour of paid employees and self-employed individuals suggest that there is 
some potential to reduce absenteeism (and the large costs associated with it) by changing the incentives associated with sick-leave for paid employees. ${ }^{10}$

Concerning the incentives for absenteeism for self-employed individuals, it would be interesting to investigate to which extent contractual arrangements and principalagent problems via the insurance company play a role. Unfortunately, we are not able to do so since our data (unlike Spierdijk et al. 2009) does not provide information on the insurance contracts of the self-employed. Two other caveats are that our data set does not contain information on the length of each occasion of absence and that it is only cross-sectional, so that unobserved heterogeneity cannot be taken into account. These limitations may be worth addressing in future research.

\footnotetext{
${ }^{10}$ Note that in 1996 the Federal Government reformed sick pay regulation in Germany so that all paid employees were entitled to only $80 \%$ (rather than 100\%) of their previous wage for the first six weeks of sickness absence. However, due to massive opposition from various sides (in particular trade unions) the reduction in sick pay was repealed in 1999. For discussions and analyses of this reform and its revocation, see Puhani and Sonderhof (2010) and Ziebarth and Karlsson (2013).
} 


\section{References}

Allebeck, Peter and Mastekaasa, Arne (2004): Chapter 5. Risk factors for sick leave - general studies, Scandinavian Journal of Public Health 32 (Suppl 63), 49-108.

Allen, Steven G. (1981): An Empirical Model of Work Attendance, Review of Economics and Statistics 63 (1), 77-87.

Angrist, Joshua D. and Pischke, Jörn-Steffen (2009): Mostly harmless econometrics. An empiricist's companion, Princeton University Press, Princeton.

Askildsen, Jan E., Bratberg, Espen, and Nilsen, Øivind A. (2005): Unemployment, labor force composition and sickness absence: a panel data study, Health Economics 14 (11), 1087-1101.

Audas, Rick and Goddard, John (2001): Absenteeism, seasonality, and the business cycle, Journal of Economics and Business 53 (4), 405-419.

Bakker, R. H., Bronsema, J., Brouwer, S., Dijkstra, G. J., Haselagger, J. J. and Groothoff, J. W. (2006): Disability insurance: can underwriting criteria for the selfemployed be based on predictors used for disability amongst employees?, Journal of Insurance Medicine 38 (4), 259-270.

Barmby, Tim, Sessions, John G. and Treble, John G. (1994): Absenteeism, efficiency wages and shirking, Scandinavian Journal of Economics 96(4), 561-566.

Beemsterboer, Willibrord, Stewart, Roy, Groothoff, Johan and Nijhuis, Frans (2009): A literature review on sick leave determinants (1984-2004), International Journal of Occupational Medicine and Environmental Health 22 (2), 169-179.

Beblo, Miriam and Ortlieb, Renate (2012): Absent from work? The impact of household and work conditions in Germany, Feminist Economics 18 (1), 73-97.

Benz, Matthias and Frey, Bruno S. (2008): Being independent is a great thing: Subjective evaluations of self-employment and hierarchy, Economica 75 (298), 362383.

Blanchflower, David G. and Oswald, Andrew J. (1998): What makes an entrepreneur?, Journal of Labor Economics 16 (1), 26-60. 
Böckerman, Petri and IImakunnas, Pekka (2008): Interaction of working conditions, job satisfaction, and sickness absences: Evidence from a representative sample of employees, Social Science \& Medicine 67 (4), 520-528.

Brown, Sarah and Sessions, John G. (1996): The Economics of Absence: Theory and Evidence, Journal of Economic Surveys 10 (1), 23-53.

Chatterji, Monojit and Tilley, Colin J. (2002): Sickness, absenteeism, presenteeism, and sick pay, Oxford Economic Papers 54 (4), 669-687.

Darr, Wendy and Johns, Gary (2008): Work Strain, Health, and Absenteeism: A Meta-Analysis, Journal of Occupational Health Psychology 13 (4), 293-318.

Dionne, Georges and Dostie, Benoit (2007): New evidence on the determinants of absenteeism using linked employer-employee data, Industrial and Labor Relations Review 61 (1), 108-120.

Engström, Per and Holmlund, Bertil (2007): Worker Absenteeism in Search Equilibrium, Scandinavian Journal of Economics 109 (3), 439-467.

Fairlie, Robert W. (2005): An extension of the Blinder-Oaxaca decomposition technique to logit and probit models, Journal of Economic and Social Measurement 30 (4), 305-316.

Frick, Bernd and Malo, Miguel M. (2008): Labor Market Institutions and Individual Absenteeism in the European Union: The Relative Importance of Sickness Benefit Systems and Employment Protection Legislation, Industrial and Labor Relations Review 47 (4), 505-529.

Hall, Anja, Siefer, Anke and Tiemann, Michael (2012): BIBB/BAuA Employment Survey of the Working Population on Qualification and Working Conditions in Germany 2012, suf_1.0, Research Data Center at BIBB (ed., data access). Federal Institute of Vocational Education and Training, Bonn. doi: 10.7803/502.12.1.1.10.

Hartman, E., Oude Vrielink, H. H. E., Huirne, R. B. M. and Metz, J. H. M. (2003): Sick leave analysis among self-employed Dutch farmers, Occupational Medicine 53 (7), 461-468. 
Heywood, John S. and Jirjahn, Uwe (2004): Teams, Teamwork and Absence, Scandinavian Journal of Economics 106 (4), 765-782.

Hundley, G. (2001): Why and when are the self-employed more satisfied with their work?, Industrial Relations 40 (2), 293-316.

Hussey, L., Turner, S., Thorley, K., McNamee, R. and Agius, R. (2012): Work-related sickness absence as reported by UK general practitioners, Occupational Medicine 62 (1), 105-111.

Hyytinen, Ari and Ruuskanen, Olli-Pekka (2007): Time Use of the Self-Employed, Kyklos 60 (1), 105-122.

Johansson, Per and Palme, Mårten (1996): Do empirical incentives affect work absence? Empirical evidence using Swedish micro data, Journal of Public Economics 59 (2), 195-218.

Johns, Gary (2009): Presenteeism in the workplace: A review and research agenda, Journal of Organizational Behavior 31 (4), 519-542.

Leigh, J. Paul (1991): Employee and job attributes as predictors of absenteeism in a national sample of workers: the importance of health and dangerous working conditions, Social Science \& Medicine 33 (2), 127-137.

Livanos, Ilias and Zangelidis, Alexandros (2013): Unemployment, Labor Market Flexibility, and Absenteeism: A Pan-European Study, Industrial Relations 52 (2), 492515.

Long, J. Scott and Freese, Jeremy (2006): Regression models for categorical dependent variables using Stata, Stata Press, College Station, $2^{\text {nd }}$ edition.

Lusinyan, Lusine and Bonato, Leo (2007): Work Absence in Europe, IMF Staff Papers 54 (3), 475-538.

Osterkamp, Rigmar and Röhn, Oliver (2007): Being on Sick Leave: Possible Explanations for Differences of Sick-leave Days Across Countries, CESifo Economic Studies 53 (1), 97-114.

Parker, Simon C. (2009): The Economics of Entrepreneurship, Cambridge University Press, Cambridge, UK, New York. 
Pedersen, J., Bjorner, J. B., Burr, H. and Christensen, K.B. (2012): Transitions between sickness absence, work, unemployment, and disability in Denmark 20042008, Scandinavian Journal of Work, Environment \& Health 38 (6), 516-526.

Pfeifer, Christian (2013): Cyclical absenteeism among private sector, public sector and self-employed workers, Health Economics 22 (3), 366-370.

Puhani, Patrick A. and Sonderhof, Katja (2010): The Effects of a Sick Pay Reform on Absence and on Health-Related Outcomes, Journal of Health Economics 29 (2), 285302.

Riphahn, Regina T., Wambach, Achim and Million, Andreas (2003): Incentive effects in the demand for health care: A bivariate panel count data estimation, Journal of Applied Econometrics 18 (4), 387-405.

Rohrbach-Schmidt, Daniela and Hall, Anja (2013): BIBB/BAuA-

Erwerbstätigenbefragung 2012, BIBB-FDZ Daten- und Methodenbericht 1/2013, Bonn.

Rose, C. E., Martin, S. W., Wannemuehler, K. A. and Plikaytis, B. D. (2006): On the use of zero-inflated and hurdle models for modeling vaccine adverse event count data, Journal of Biopharmaceutical Statistics 16 (4), 463-481.

Spierdijk, Laura, van Lomwel, Gijsbert and Peppelman, Wilko (2009): The determinants of sick leave durations of Dutch self-employed, Journal of Health Economics 28 (6), 1185-1196.

Steers, Richard M. and Rhodes, Susan R. (1978): Major influences on employee attendance: A process model, Journal of Applied Psychology 63 (4), 391-407.

Thalmaier, Anja (2002): Eine ökonomische Analyse von Fehlzeiten, Frankfurt/Main.

Yelin, E., Meenan, R., Nevitt, M. and Epstein, W. (1980): Work disability in rheumatoid arthritis: effects of disease, social, and work factors, Annals of Internal Medicine 93 (4), 551-556.

Ziebarth, Nicolas A. and Karlsson, Martin (2013): The Effects of Expanding the Generosity of the Statutory Sickness Insurance System, Journal of Applied Econometrics online first 25 March 2013, DOI: 10.1002/jae.2317. 
Table 1 Descriptive Statistics

\begin{tabular}{|c|c|c|c|c|}
\hline & \multicolumn{2}{|c|}{$\begin{array}{l}\text { Self-employed } \\
(N=1,700)\end{array}$} & \multicolumn{2}{|c|}{$\begin{array}{c}\text { Paid } \\
\text { employees } \\
(N=9,837)\end{array}$} \\
\hline & Mean & $\begin{array}{l}\text { Std. } \\
\text { Dev. }\end{array}$ & Mean & $\begin{array}{l}\text { Std. } \\
\text { Dev. }\end{array}$ \\
\hline Sick leave during the last 12 months & & & & \\
\hline Ever (dummy) & 0.22 & 0.41 & 0.51 & 0.50 \\
\hline Number of occasions & 0.37 & 1.01 & 0.87 & 1.34 \\
\hline Number of workdays & 3.15 & 14.53 & 9.32 & 27.38 \\
\hline $\begin{array}{l}\text { Sick leave during the last } 12 \text { months conditional on } \\
\text { ever having been absent }\end{array}$ & & & & \\
\hline Number of occasions & 1.69 & 1.56 & 1.71 & 1.44 \\
\hline Number of workdays & 14.34 & 28.35 & 18.22 & 36.11 \\
\hline $\begin{array}{l}\text { Workplace attendance despite sickness during the } \\
\text { last } 12 \text { months }\end{array}$ & & & & \\
\hline Ever (dummy) & 0.48 & 0.50 & 0.53 & 0.50 \\
\hline Number of occasions & 2.20 & 6.01 & 1.93 & 4.12 \\
\hline Number of workdays & 5.21 & 17.58 & 5.93 & 14.30 \\
\hline Good to excellent health status (dumm & 0.91 & 0.28 & 0.87 & 0.34 \\
\hline $\begin{array}{l}\text { Number of different types of afflictions that received } \\
\text { medical treatment during the last } 12 \text { months }\end{array}$ & 1.23 & 2.16 & 1.72 & 2.69 \\
\hline Weekly working hours & 45.19 & 17.02 & 38.23 & 11.24 \\
\hline $\begin{array}{l}\text { Ability of taking family and private interests into } \\
\text { account when scheduling working time (dummy: } \\
1=\text { often, } 0=\text { =sometimes/never) }\end{array}$ & 0.57 & 0.50 & 0.60 & 0.49 \\
\hline Job satisfaction & & & & \\
\hline Very satisfied (dummy) & 0.41 & 0.49 & 0.27 & 0.45 \\
\hline Female (dummy) & 0.37 & 0.48 & 0.48 & 0.50 \\
\hline Age (years) & 49.80 & 10.57 & 44.73 & 10.60 \\
\hline University (of applied sciences) degree (dummy) & 0.43 & 0.49 & 0.20 & 0.40 \\
\hline
\end{tabular}

Note: The data set used is the BIBB/BAuA Employment Survey 2012. 
Table 2 Probit estimates of ever having been absent (average partial effects)

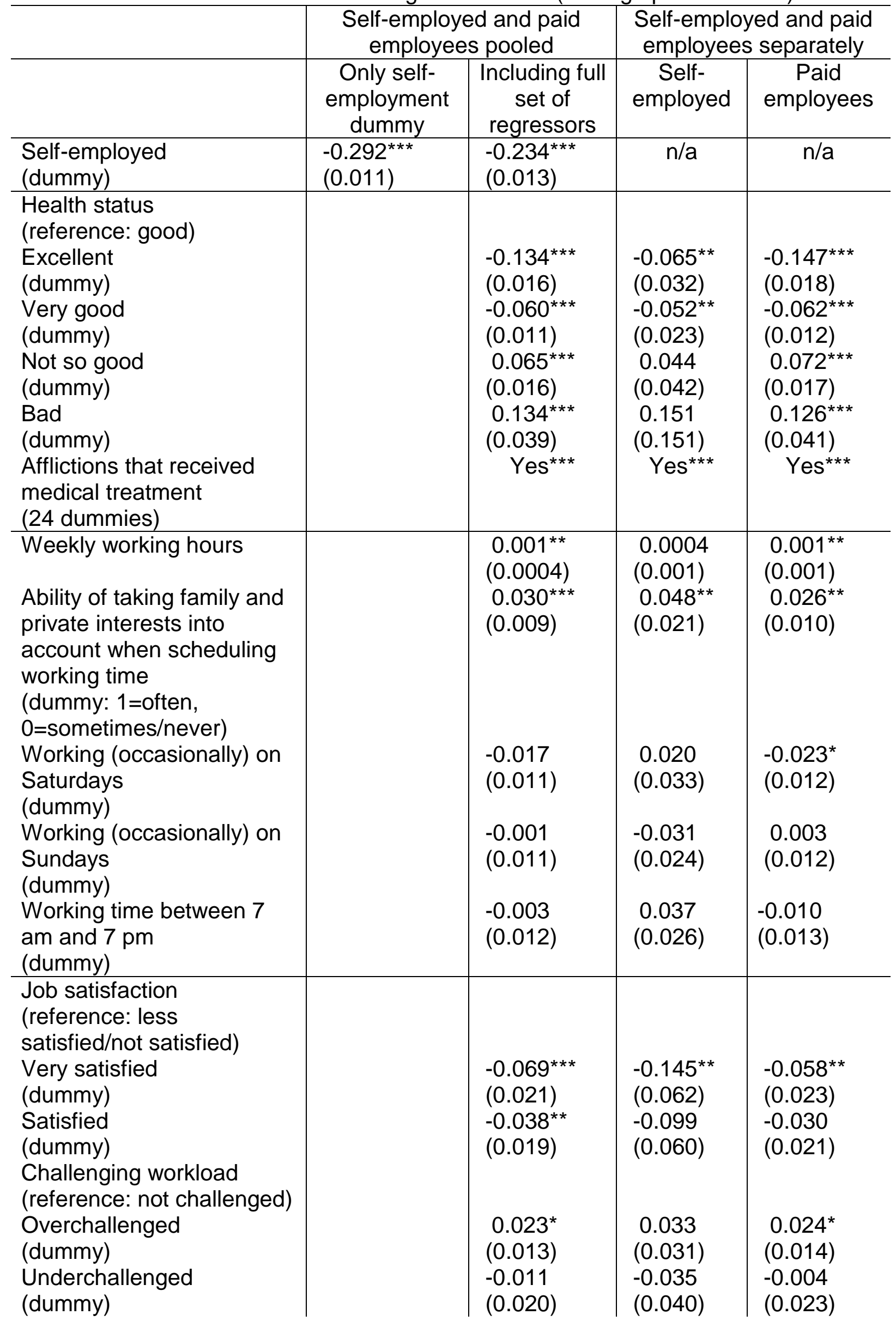




\begin{tabular}{|c|c|c|c|c|}
\hline $\begin{array}{l}\text { Emotional strain at work } \\
\text { (reference: never) } \\
\text { Often } \\
\text { (dummy) } \\
\text { Sometimes } \\
\text { (dummy) } \\
\text { Rarely } \\
\text { (dummy) } \\
\text { Stressful working } \\
\text { conditions } \\
\text { (23 dummies) }\end{array}$ & & $\begin{array}{l}0.007 \\
(0.018) \\
0.009 \\
(0.012) \\
0.001 \\
(0.011) \\
\text { Yes }^{\star \star \star}\end{array}$ & $\begin{array}{l}-0.006 \\
(0.038) \\
0.039 \\
(0.028) \\
-0.003 \\
(0.026) \\
\text { Yes }\end{array}$ & $\begin{array}{l}0.009 \\
(0.020) \\
0.003 \\
(0.013) \\
0.002 \\
(0.012) \\
\text { Yes*** }\end{array}$ \\
\hline $\begin{array}{l}\text { Female } \\
\text { (dummy) } \\
\text { Age } \\
\text { (years) } \\
\text { Migration background } \\
\text { (dummy) } \\
\text { Professional qualification } \\
\text { (reference: none) }\end{array}$ & & $\begin{array}{l}0.012 \\
(0.011) \\
-0.006^{\star \star \star} \\
(0.0005) \\
-0.027^{\star} \\
(0.015)\end{array}$ & $\begin{array}{l}0.036 \\
(0.024) \\
-0.005^{\star \star \star} \\
(0.001) \\
-0.008 \\
(0.033)\end{array}$ & $\begin{array}{l}0.010 \\
(0.012) \\
-0.006^{\star \star \star} \\
(0.001) \\
-0.032^{\star} \\
(0.017)\end{array}$ \\
\hline $\begin{array}{l}\text { University (of applied } \\
\text { sciences) degree } \\
\text { (dummy) }\end{array}$ & & $\begin{array}{l}0.047^{* *} \\
(0.020)\end{array}$ & $\begin{array}{l}-0.015 \\
(0.044)\end{array}$ & $\begin{array}{c}0.056 * \star \\
(0.023)\end{array}$ \\
\hline $\begin{array}{l}\text { Master craftsmen/ state } \\
\text { certified technician/ } \\
\text { business administrator } \\
\text { (dummy) }\end{array}$ & & $\begin{array}{c}0.014 \\
(0.022)\end{array}$ & $\begin{array}{l}-0.018 \\
(0.049)\end{array}$ & $\begin{array}{c}0.023 \\
(0.025)\end{array}$ \\
\hline $\begin{array}{l}\text { Vocational training } \\
\text { (dummy) } \\
\text { Living together with partner } \\
\text { (dummy) } \\
\text { Young children in } \\
\text { household } \\
\text { (dummy) }\end{array}$ & & $\begin{array}{l}0.002 \\
(0.017) \\
-0.020 \star \star \\
(0.009) \\
0.017 \\
(0.012)\end{array}$ & $\begin{array}{l}-0.053 \\
(0.043) \\
0.005 \\
(0.022) \\
0.033 \\
(0.028)\end{array}$ & $\begin{array}{l}0.011 \\
(0.019) \\
-0.023^{\star *} \\
(0.010) \\
0.015 \\
(0.013)\end{array}$ \\
\hline $\begin{array}{l}\text { Region ("Bundesland") } \\
\text { (16 dummies) } \\
\text { Industry } \\
\text { ( } 21 \text { dummies) }\end{array}$ & & $\begin{array}{l}\text { Yes*** } \\
\text { Yes*** }\end{array}$ & $\begin{array}{l}\text { Yes } \\
\text { Yes }\end{array}$ & $\begin{array}{l}\text { Yes*** } \\
\text { Yes*** }\end{array}$ \\
\hline $\begin{array}{l}\text { Number of observations } \\
\text { Log likelihood }\end{array}$ & $\begin{array}{c}11,537 \\
-7,710.4 \\
\end{array}$ & $\begin{array}{c}11,537 \\
-6,869.9 \\
\end{array}$ & $\begin{array}{r}1,698 \\
-757.9 \\
\end{array}$ & $\begin{array}{c}9,837 \\
-6,041.4 \\
\end{array}$ \\
\hline
\end{tabular}

Notes: The data set used is the BIBB/BAuA Employment Survey 2012. Standard

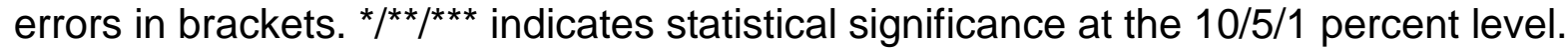


Table 3 Truncated negative binomial estimates of number of absent days conditional on ever having been absent (average partial effects)

\begin{tabular}{|c|c|c|c|c|}
\hline & \multicolumn{2}{|c|}{$\begin{array}{l}\text { Self-employed and paid } \\
\text { employees pooled }\end{array}$} & \multicolumn{2}{|c|}{$\begin{array}{l}\text { Self-employed and paid } \\
\text { employees separately }\end{array}$} \\
\hline & $\begin{array}{l}\text { Only self- } \\
\text { employment } \\
\text { dummy }\end{array}$ & $\begin{array}{l}\text { Including full } \\
\text { set of } \\
\text { regressors }\end{array}$ & $\begin{array}{c}\text { Self- } \\
\text { employed }\end{array}$ & $\begin{array}{l}\text { Paid } \\
\text { employees }\end{array}$ \\
\hline $\begin{array}{l}\text { Self-employed } \\
\text { (dummy) }\end{array}$ & $\begin{array}{l}-3.187^{\star \star \star} \\
(0.851)\end{array}$ & $\begin{array}{l}-1.551 \\
(1.156)\end{array}$ & $n / a$ & $n / a$ \\
\hline $\begin{array}{l}\text { Health status } \\
\text { (reference: good) } \\
\text { Excellent } \\
\text { (dummy) } \\
\text { Very good } \\
\text { (dummy) } \\
\text { Not so good } \\
\text { (dummy) } \\
\text { Bad } \\
\text { (dummy) } \\
\text { Afflictions that received } \\
\text { medical treatment } \\
\text { (24 dummies) }\end{array}$ & & $\begin{array}{l}-4.925^{\star \star \star} \\
(0.786) \\
-2.905^{\star \star \star} \\
(0.584) \\
7.128^{\star \star \star} \\
(1.063) \\
23.933^{\star \star \star} \\
(4.138) \\
\text { Yes } \\
\text { Yes }^{\star \star \star}\end{array}$ & $\begin{array}{c}-10.836^{\star \star \star} \\
(2.154) \\
-7.182^{\star \star \star} \\
(1.956) \\
-1.942 \\
(3.342) \\
34.293 \\
(34.451) \\
\text { Yes }^{\star \star \star}\end{array}$ & $\begin{array}{l}-4.390^{\star \star \star} \\
(0.861) \\
-2.516^{\star \star \star} \\
(0.626) \\
7.206^{\star \star \star} \\
(1.102) \\
24.574^{\star \star \star} \\
(4.287) \\
\text { Yes }^{\star \star \star}\end{array}$ \\
\hline $\begin{array}{l}\text { Weekly working hours } \\
\text { Ability of taking family and } \\
\text { private interests into } \\
\text { account when scheduling } \\
\text { working time } \\
\text { (dummy: } 1=\text { often, } \\
0=\text { sometimes/never) }\end{array}$ & & $\begin{array}{c}0.130 * \star \star \\
(0.032) \\
0.921 \\
(0.636)\end{array}$ & $\begin{array}{c}0.129 * \\
(0.070) \\
1.227 \\
(2.275)\end{array}$ & $\begin{array}{c}0.142^{\star \star \star} \\
(0.036) \\
0.594 \\
(0.668)\end{array}$ \\
\hline $\begin{array}{l}\text { Working (occasionally) on } \\
\text { Saturdays } \\
\text { (dummy) }\end{array}$ & & $\begin{array}{l}-0.392 \\
(0.745)\end{array}$ & $\begin{array}{l}-4.166 \\
(4.358)\end{array}$ & $\begin{array}{l}-0.439 \\
(0.771)\end{array}$ \\
\hline $\begin{array}{l}\text { Working (occasionally) on } \\
\text { Sundays } \\
\text { (dummy) }\end{array}$ & & $\begin{array}{l}0.452 \\
(0.756)\end{array}$ & $\begin{array}{r}4.426^{*} \\
(2.253)\end{array}$ & $\begin{array}{l}-0.184 \\
(0.784)\end{array}$ \\
\hline $\begin{array}{l}\text { Working time between } 7 \\
\text { am and } 7 \mathrm{pm} \\
\text { (dummy) }\end{array}$ & & $\begin{array}{l}-2.219^{\star *} \\
(0.860)\end{array}$ & $\begin{array}{l}6.008^{\star \star \star} \\
(2.300)\end{array}$ & $\begin{array}{l}-2.716^{\star \star \star} \\
(0.911)\end{array}$ \\
\hline $\begin{array}{l}\text { Job satisfaction } \\
\text { (reference: less } \\
\text { satisfied/not satisfied) }\end{array}$ & & & & \\
\hline $\begin{array}{l}\text { Very satisfied } \\
\text { (dummy) } \\
\text { Satisfied }\end{array}$ & & $\begin{array}{l}1.736 \\
(1.259) \\
0.881\end{array}$ & $\begin{array}{l}0.132 \\
(4.977) \\
-1.704\end{array}$ & $\begin{array}{c}1.948 \\
(1.312) \\
1.128\end{array}$ \\
\hline $\begin{array}{l}\text { (dummy) } \\
\text { Challenging workload } \\
\text { (reference: not challenged) }\end{array}$ & & (1.074) & $(4.430)$ & (1.114) \\
\hline $\begin{array}{l}\text { Overchallenged } \\
\text { (dummy) }\end{array}$ & & $\begin{array}{l}-0.819 \\
(0.782)\end{array}$ & $\begin{array}{l}-1.226 \\
(2.655)\end{array}$ & $\begin{array}{l}-0.949 \\
(0.824)\end{array}$ \\
\hline Underchallenged & & $3.931^{\star \star}$ & 15.299 & $3.619^{\star \star}$ \\
\hline
\end{tabular}




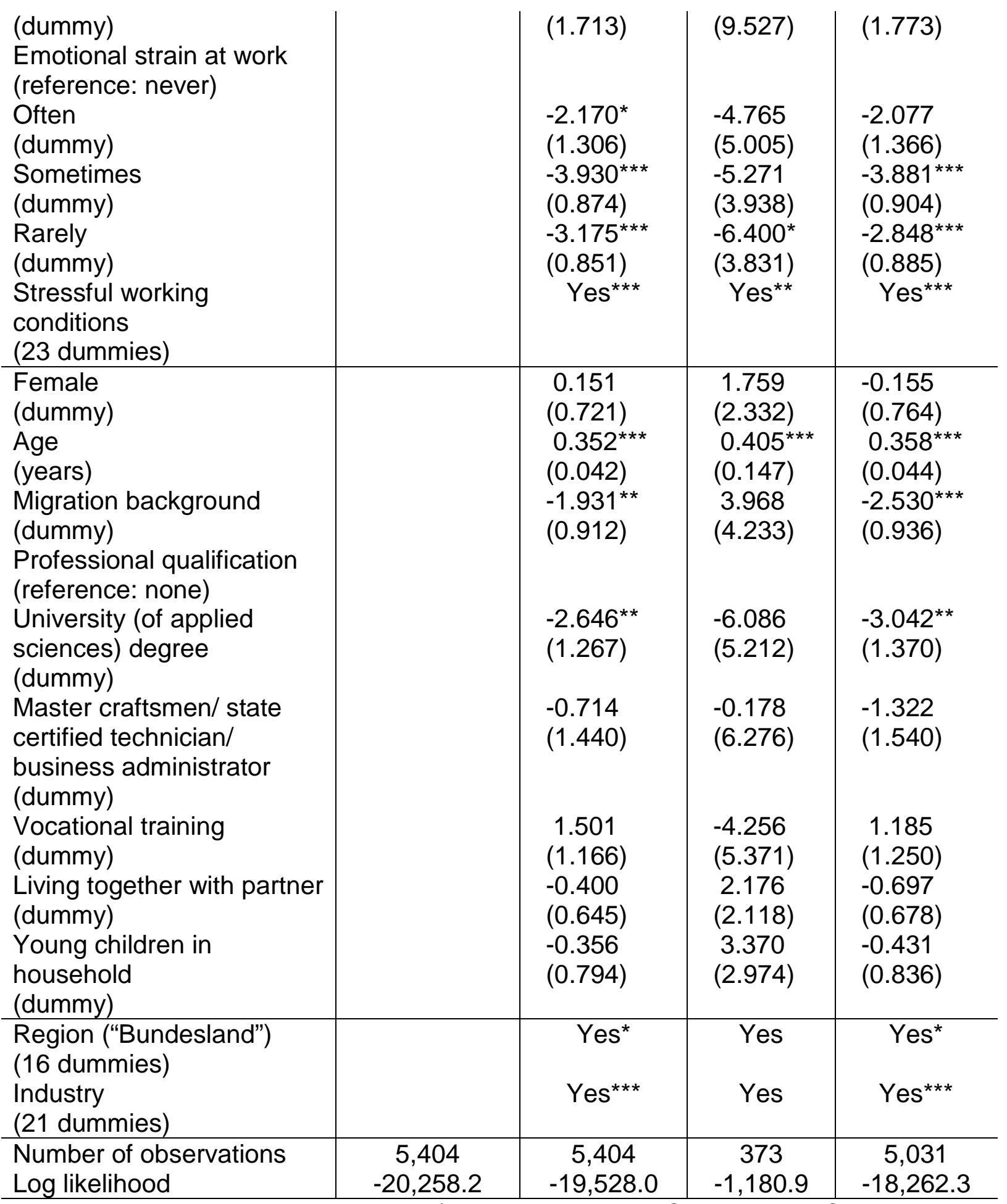

Notes: The data set used is the BIBB/BAuA Employment Survey 2012. Standard

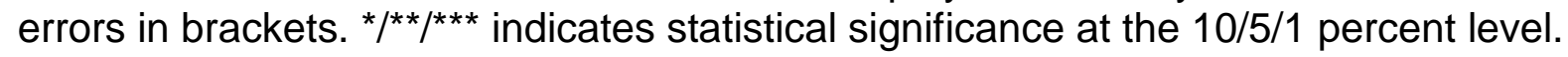

